
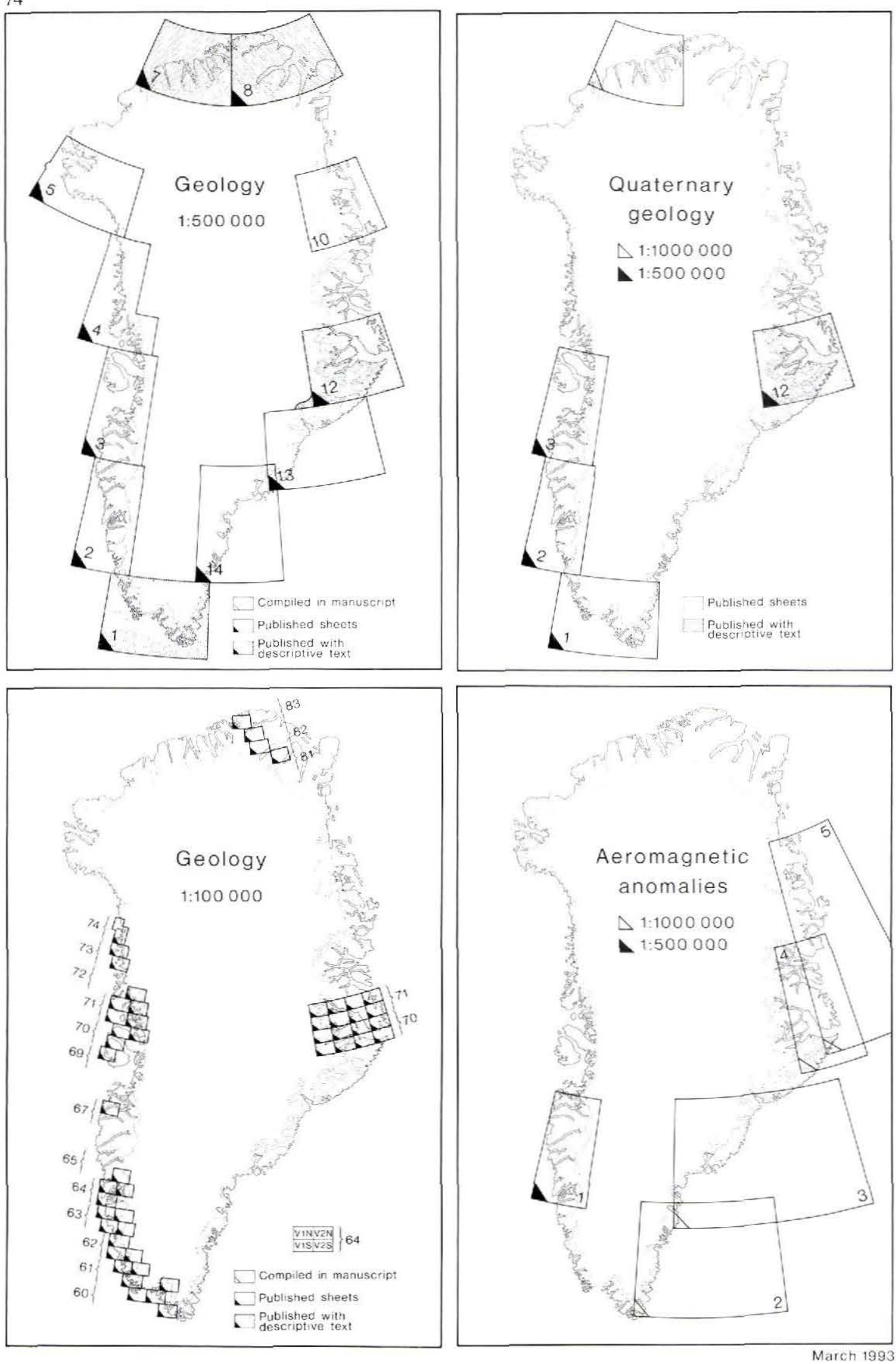

Fig. 1. Map sheets published and in preparation by the Survey. 


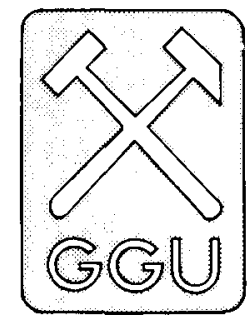

\section{Publications of the Geological Survey of Greenland 1992}

\section{Maps and map sheet descriptions}

Sheets 7 and 8 . Nyeboe Land and Peary Land. Geological map of Greenland, 1:500 000. Descriptive text. The geology of North Greenland, a region characterised by Proterozoic, Palaeozoic and Mesozoic sedimentary basins, SilurianDevonian orogenic events (Ellesmerian, Caledonian) and Mesozoic-Tertiary block faulting and thrusting. 1992 by N. Henriksen. 40 pp.

Upper Proterozonic to Devonian, central fjord zone, East Greenland. 1:250 000 by H.-J. Bengaard. 1992.

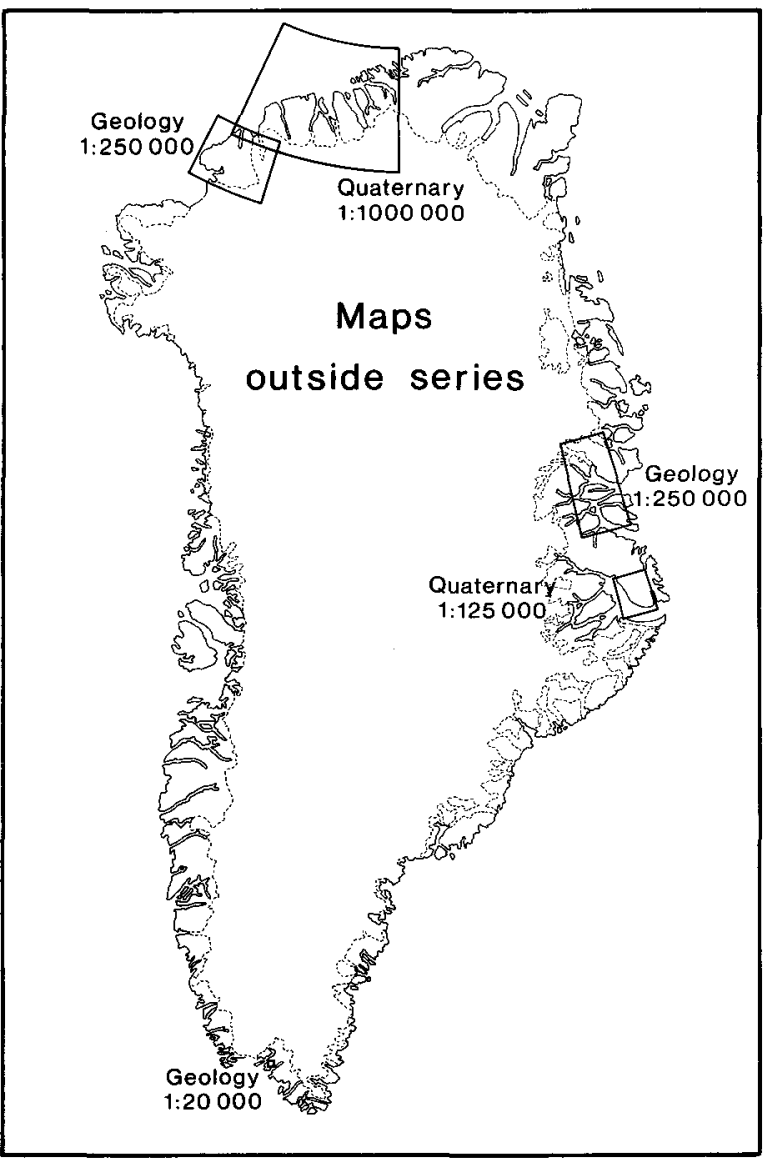

Fig. 2. Special map sheets published by the Survey.

\section{Bulletins (Bull. Grønlands geol. Unders.)}

162 Upper Cretaceous - Lower Tertiary decapod crustaceans from West Greenland. 1992 by J. S. H. Collins \& H. W. Rasmussen. $46 \mathrm{pp}$.

163 Upper Llandovery and Wenlock Cyrtograptus from the Silurian Peary Land Group, North Greenland. 1992 by M. Bjerreskov. 31 pp.

\section{Reports (Rapp. Grønlands geol. Unders.)}

153 Quaternary geology of western and central North Greenland. 1992 by M. Kelly \& O. Bennike. 34 pp.

154 Current research. Short scientific papers. 1992.59 pp. (4 articles).

155 Current research including Report of Activities, 1991. 1992 edited by A. K. Higgins \& M. Sønderholm. 93 pp. (18 articles).

156 Geological analysis of mapping using multi-model photogrammetry. 1992 edited by K. S. Dueholm \& A. K. Pedersen. 72 pp. (8 articles).

157 Lithostratigraphy and geological setting of Upper Proterozoic shoreline-shelf deposits, Hagen Fjord Group, eastern North Greenland. 1992 by L. B. Clemmensen \& H. F. Jepsen. 27 pp.

158 Glacier inventory and atlas of West Greenland. 1992 by A. Weidick, C. E. Bøggild \& N. T. Knudsen. 194 pp., 22 figs, 6 tables (incl. 47 pp. text, 45 pp. data tables \& 100 pp. atlas).

\section{Open File Series}

92/1 Geochemical investigation of heavy mineral concentrates from stream sediments in southern West Greenland, $62^{\circ} 30^{\prime}$ to $64^{\circ} 00^{\prime} \mathrm{N}-1991$ results. 1992 by P. Erfurt, P. W. U. Appel \& M. Lind. 39 pp.

92/2 The Grønnedal-Ika alkaline complex in South Greenland. Review of geoscientific data relevant to exploration. 1992 by J. Bondam 28 pp.

92/3 Gold mineralisation in Precambrian supracrustal rocks on southern Nuussuaq, central West Greenland: 1991 results. 1992 by B. Thomassen \& T. Tukiainen. 31 pp.

92/4 Gold, arsenic and antimony in stream sediment related to supracrustal units between Arfersiorfik and Qarajaq Isfjord $\left(68^{\circ} \mathrm{N}\right.$ to $\left.70^{\circ} 30^{\prime} \mathrm{N}\right)$, West Greenland. 1992 by $\mathrm{A}$. Steenfelt. $11 \mathrm{pp}$. 
92/5 Chromite in the Fiskenæsset stratiform anorthosite complex, West Greenland. 1992 by P. W. U. Appel. 14 pp.

92/6 Graphite occurrences in Greenland. A review. 1992 by J. Bondam. 32 pp.

92/7 Reconnaissance geochemical exploration of map sheet 68 V.2 $\left(67^{\circ} 55^{\prime}\right.$ to $68^{\circ} 45^{\prime} \mathrm{N}, 50^{\circ} 15^{\prime}$ to $\left.52^{\circ} 45^{\prime} \mathrm{W}\right)$, West Greenland. 1992 by A. Steenfelt, E. Dam \& J. P. Nielsen. $14 \mathrm{pp}$.

92/8 Lower Palaeozoic outer shelf and slope lithostratigraphy, Franklinian basin, North Greenland. 1992 by A. K. Higgins, N. J. Soper \& N. C. Davis. 43 pp.

92/9 The nature of the basal section in the Kangâmiut-1 well, offshore West Greenland. 1992 by J. A. Chalmers. 22 pp.

92/10 Reconnaissance geochemical mapping of eastern South Greenland $\left(60^{\circ} 30^{\prime}\right.$ to $\left.62^{\circ} 30^{\prime} \mathrm{N}\right) .1992$ by A. Steenfelt, E. Dam \& P. Erfurt. 12 pp.

\section{Scientific articles}

Appel, P. W. U. 1992: Bjørnesund Project, West Greenland. Rapp. Grønlands geol. Unders. 155, 24-27.

Appel, P. W. U. 1992: Tourmalinites in supracrustal rocks in the Bjørnesund area, West Greenland. Rapp. Grønlands geol. Unders. 155, 73-78.

Bjerreskov, M. 1992: Upper Llandovery and Wenlock Cyrtograptus from the Silurian Peary Land Group, North Greenland. Bull. Grønlands geol. Unders. 163, 31 pp.

Braithwaite, R. J. 1992: Degree-day factor, energy balance, and the increased melting of the Greenland ice sheet under a warmer climate. Rapp. Grønlands geol. Unders. 155, 79-83.

Braithwaite, R. J. 1992: Sea level rise caused by increased melting of the Greenland ice sheet. Proc. int. Conf. Climatic impacts on the environment and society (CIES), Tsukubia, Ibaraki, Japan, 1991, B-57-B-62.

Braithwaite, R. J., Reeh, N. \& Weidick, A. 1992: Greenland glaciers and the 'greenhouse effect', status 1991. Rapp. Grønlands geol. Unders. 155, 9-15.

Braithwaite, R. J., Pfeffer, W. T., Blatter, H. \& Humphrey, N. F. 1992: Meltwater refreezing in the accumulation area of the Greenland ice sheet: Pâkitsoq, summer 1991. Rapp. Grønlands geol. Unders. 155, 13-17.

Braithwaite, R. J., Olesen, O. B. \& Thomsen, H. H. 1992: Calculated variations of annual ablation at the margin of the Greenland ice sheet, West Greenland, 1961-1990. J. Glaciol. 38, 266-272.

Christiansen, F. G. \& Pulvertaft, T. C. R. 1992: Petroleum geological activities in 1991: reassessment of earlier exploration, and improvement of information service to industry. Rapp. Grønlands geol. Unders. 155, 28-30.

Christiansen, F. G., Dam, G., McIntyre, D. J., Nøhr-Hansen, H., Pedersen, G. L. \& Sønderholm, M. 1992: Renewed petroleum geological studies onshore West Greenland. Rapp. Grønlands geol. Unders. 155, 31-35.

Christiansen, F. G., Larsen, H. C., Marcussen, C., Hansen, K., Krabbe, H., Larsen, L. M., Piasecki, S., Stemmerik, L. \& Watt, W. S. 1992: Uplift study of the Jameson Land basin, East Greenland. Norsk geol. Tidsskr. 72, 291-294.

Christiansen, F. G., Dam, G., Piasecki, S. \& Stemmerik, L.
1992: A review of Upper Palaeozoic and Mesozoic source rocks from onshore East Greenland. In Spencer, A. M. (ed.) Generation, accumulation and production of Europe's hydrocarbons II. Spec. Publ. Eup. Ass. Petrol. Geosci. 2, 151-161.

Christiansen, F. G., Piasecki, S. \& Stemmerik, L. 1991 [issued 1992]: Petroleum resources, North Greenland. In Trettin, H. P. (ed.) Geology of the Innuitian orogen and arctic platform of Canada and Greenland, 525-529. Geology of Canada 3, Chapter 20 (also Géologie du Canada and Geology of North America, Vol. E). Calgary: Geological Survey of Canada.

Christie, R. L. \& Dawes, P. R. 1991 [issued 1992]: Geographic and geological exploration. In Trettin, H. P. (ed.) Geology of the Innuitian orogen and arctic platform of Canada and Greenland, 7-25. Geology of Canada 3, Chapter 2 (also Géologie du Canada and Geology of North America, Vol. E). Calgary: Geological Survey of Canada.

Clemmensen, L. B. \& Jepsen, H. F. 1992: Lithostratigraphy and geological setting of Upper Proterozoic shoreline-shelf deposits, Hagen Fjord Group, eastern North Greenland. Rapp. Grønlands geol. Unders. 157, 27 pp.

Collins, J. S. H. \& Rasmussen, H. W. 1992: Upper Cretaceous - Lower Tertiary decapod crustaceans from West Greenland. Bull. Grønlands geol. Unders. 162, 46 pp.

Dam, G. \& Surlyk, F. 1992: Forced regressions in a large waveand storm-dominated anoxic lake, Rhaetian-Sinemurian Kap Stewart Formation, East Greenland. Geology 20, 749752.

Dawes, P. R. 1992: New geological map of the Thule region, North-West Greenland. Rapp. Grønlands geol. Unders. 155, $42-47$.

Dawes, P. R. \& Christie, R. L. 1991 [issued 1992]: Geomorphic regions. In Trettin, H. P. (ed.) Geology of the Innuitian orogen and arctic platform of Canada and Greenland, 29-56. Geology of Canada 3, Chapter 3 (also Géologie du Canada and Geology of North America, Vol. E). Calgary: Geological Survey of Canada.

Dawes, P. R. \& Schønwandt, H. K. 1992: Geological setting of Precambrian supracrustal belts: a fundamental part of mineral resource evaluation in Greenland. Rapp. Gronlands geol. Unders. 155, 19-23.

Dueholm, K. S. \& Pedersen, A. K. (ed.) 1992: Geological analysis and mapping using multi-model photogrammetry. Rapp. Grønlands geol. Unders. 156, 72 pp.

Dueholm, K. S. \& Pedersen, A. K. 1992: The application of multi-model photogrammetry in geology - status and development trends. Rapp. Grønlands geol. Unders. 156, 69-72.

Garde, A. A. 1992: Interpretation of flat-lying Precambrian structure by geological photogrammetry along a $65 \mathrm{~km}$ coastal profile in Nuussuaq, West Greenland. Rapp. Grønlands geol. Unders. 156, 35-40.

Garde, A. A. 1992: Close-range geological photogrammetry studies: field and laboratory procedures with examples from prograde granulite facies orthogneisses, Kerala, South India. Rapp. Grønlands geol. Unders. 156, 53-62.

Ghisler, M. 1992: Review of the Survey's activities in 1991. Rapp. Grønlands geol. Unders. 155, 7-8. 
Hayashi, M., Maruyama, S. \& Appel, P. [W. U.] 1992: The Archaean regional metamorphisn in the Isua region, southern West Greenland. Evolving Earth Symposium, Okazaki, Japan, 1992, 114-123.

Henriksen, N. 1992: Geological map of Greenland 1:500 000. Descriptive text. Nyeboe Land, Sheet 7. Peary Land, Sheet 8. The geology of North Greenland, a region characterised by Proterozoic, Palaeozoic and Mesozoic sedimentary basins, Silurian-Devonian orogenic events (Ellesmerian, Caledonian) and Mesozoic-Tertiary block faulting and thrusting. 40 pp., 19 figs, 1 table. Copenhagen: Grønlands Geologiske Undersøgelse.

Higgins, A. K. \& Soper, N. J. 1991 [issued 1992]: Metamorphism. In Devonian - Early Carboniferous deformation and metamorphism, North Greenland. In Trettin, H. P. (ed.) Geology of the Innuitian orogen and arctic platform of Canada and Greenland, 289-290. Geology of Canada 3, Chapter 11 (also Géologie du Canada and Geology of North America, Vol. E). Calgary: Geological Survey of Canada.

Higgins, A. K., Ineson, J. R., Peel, J. S., Surlyk, F. \& Sønderholm, M. 1991b [issued 1992]: Cambrian to Silurian basin development and sedimentation, North Greenland. In Trettin, H. P. (ed.) Geology of the Innuitian orogen and arctic platform of Canada and Greenland, 111-161. Geology of Canada 3, Chapter 7 (also Géologie du Canada and Geology of North America, Vol. E). Calgary: Geological Survey of Canada.

Holm, P. M., Hald, N. \& Nielsen, T. F. D. 1992: Contrasts in composition and evolution of Tertiary CFBs between West and East Greenland and their relations to the establishment of the Icelandic mantle plume. In Storey, B. C., Alabaster, T. \& Pankhurst, R. J. (ed.) Magmatism and the causes of continental break-up. Spec. Publ. geol. Soc., Lond. 68, 349364.

Humlum, O. 1992: Geomorphological applications of multimodel photogrammetry. Rapp. Grønlands geol. Unders. 156, 63-67.

Kalsbeek, F. 1992: The statistical distribution of the mean squared weighted deviation - comment: Isochrons, errorchrons, and the use of MSWD-values. Chem. Geol. (Isotope Geosci. Sect.) 94, 241-242.

Kalsbeek, F. 1992: Large-scale albitisation of siltstones on Qeqertakavsak island, northeast Disko Bugt, West Greenland. Chem. Geol. 95, 213-233.

Kalsbeek, F. \& Christiansen, F. G. 1992: Disko Bugt Project 1991, West Greenland. Rapp. Grønlands geol. Unders. 155, 36-41.

Kelly, M. \& Bennike, O. 1992: Quaternary geology of western and central North Greenland. Rapp. Grønlands geol. Unders. 153, 34 pp. map.

Lane, P. D. \& Rushton, A. W. A. 1992: A problematical trilobite from the Lower Cambrian of Freuchen Land, central North Greenland. Rapp. Grønlands geol. Unders. 154, 5-12.

Larsen, H. C. \& Marcussen, C. 1992: Sill-intrusion, flood basalt emplacement and deep crustal structure of the Scoresby Sund region, East Greenland. In Storey, B. C., Alabaster, T. \& Pankhurst, R. J. (ed.) Magmatism and the causes of continental break-up. Spec. Publ. geol. Soc., Lond. 68, 365-386.

Larsen, L. M. \& Pedersen, A. K. 1992: Volcanic marker horizons in the upper part of the Maligât Formation on eastern Disko and Nuussuaq, Tertiary of West Greenland: syn- to post-volcanic basin movements. Rapp. Grønlands geol. Unders. 155, 85-93.

Larsen, L. M. \& Rex. D. C. 1992: A review of the $2500 \mathrm{Ma}$ span of alkaline-ultramafic, potassic and carbonatitic magmatism in West Greenland. Lithos 28, 367-402.

Larsen, L. M., Pedersen, A. K., Pedersen, G. K. \& Piasecki, S. 1992: Timing and duration of Early Tertiary volcanism in the North Atlantic: new evidence from West Greenland. In Storey, B. C., Alabaster, T. \& Pankhurst, R. J. (ed.) Magmatism and the causes of continental break-up. Spec. Publ. geol. Soc., Lond. 68, 321-333. 7

Olsen, T. 1992: Photogrammetric mapping of fluvial channel sand-bodies in the Atane Formation at Paatuut, Nuussuaq, central West Greenland. Rapp. Gronlands geol. Unders. 156, 41-46.

Pedersen, A. K. \& Dueholm, K. S. 1992: New methods for the geological analysis of Tertiary volcanic formations on Nuussuaq and Disko, central West Greenland, using multi-model photogrammetry. Rapp. Grønlands geol. Unders. 156, 19-34.

Pedersen, G. K. 1992: An application of multi-model photogrammetry in the study of a Tertiary shale unit, north-east Disko, West Greenland. Rapp. Gronlands geol. Unders. 156, 47-51.

Pedersen, G. K. \& Pulvertaft, T. C. R. 1992: The nonmarine Cretaceous of the West Greenland Basin, onshore West Greenland. Cretaceous Res. 13, 263-272.

Peel, J. S., Morris, S. C. \& Ineson, J. R. 1992: A second glimpse of Early Cambrian life: new collections from Sirius Passet, North Greenland. Rapp. Grønlands geol. Unders. 155, 48-50.

Piasecki, S., Larsen, L. M., Pedersen, A. K. \& Pedersen, G. K. 1992: Palynostratigraphy of the Lower Tertiary volcanics and marine clastic sediments in the southern part of the West Greenland Basin: implications for the timing and duration of the volcanism. Rapp. Gronlands geol. Unders. 154, 13-31.

Schønwandt, H. K. 1992: GGU's mineral resource activities and their role for the mineral industry. Rapp. Grønlands geol. Unders. 155, 17-19.

Skjernaa, L. 1992: A lamproite stock with ellipsoidal phlogopite nodules at Oqaitsúnguit, Disko Bugt, central West Greenland. Rapp. Gronlands geol. Unders. 154, 33-47.

Soper, N. J. \& Higgins, A. K. 1991 [issued 1992]: Late Cretaceous - Early Tertiary deformation, North Greenland. In Trettin, H. P. (ed.) Geology of the Innuitian orogen and arctic platform of Canada and Greenland 461-465. Geology of Canada 3, Chapter 16 (also Géologie du Canada and Geology of North America, Vol. E). Calgary: Geological Survey of Canada.

Soper, N. J. \& Higgins, A. K. 1991 [issued 1992]: Deformation. In Devonian - Early Carboniferous deformation and metamorphisn, North Greenland. In Trettin, H. P. (ed.) 
Geology of the Innuitian orogen and arctic platform of Canada and Greenland, 283-288. Geology of Canada 3, Chapter 11 (also Géologie du Canada and Geology of North America, Vol. E). Calgary: Geological Survey of Canada.

Steenfelt, A. 1991 [issued 1992]: Economic mineral resources; North Greenland. In Trettin, H. P. (ed.) Geology of the Innuitian orogen and arctic platform of Canada and Greenland 539-541. Geology of Canada 3, Chapter 20 (also Géologie du Canada and Geology of North America, Vol. E). Calgary: Geological Survey of Canada.

Steenfelt, A. 1991: High-technology metals in alkaline and carbonatitic rocks in Greenland: recognition and exploration. J. geochem. Explor. 40, 263-279.

Strachan, R. A., Holdsworth, R. E., Friderichsen, J. D. \& Jepsen, H. F. 1992: Regional Caledonian structure within an oblique convergence zone, Dronning Louise Land, NE Greenland. J. geol. Soc. Lond. 149, 359-371.
Taylor, P. N., Kalsbeek, F. \& Bridgwater, D. 1992: Discrepancies between neodymium, lead and strontium model ages from the Precambrian of southern East Greenland: evidence for a Proterozoic granulite-facies event affecting Archaean gneisses. Chem. Geol. (Isotope Geosci. Sect.) 94, 281-291.

Thomassen, B. 1992: The gold and base metal potential of the Lower Proterozoic Karrat Group, West Greenland. Rapp. Grønlands geol. Unders. 155, 57-66.

Weidick, A. 1992: Jakobshavn Isbræ area during the climatic optimum. Rapp. Grønlands geol. Unders. 155, 67-72.

Weidick, A., Bøggild, C. E. \& Knudsen, N. T. 1992: Glacier inventory and atlas of West Greenland. Rapp. Grønlands geol. Unders. 158, 194 pp., 22 figs, 6 tables (incl. 47 pp. text, 45 pp. data tables \& 100 pp. atlas).

Winther, [K.] T. 1992: Feldspar megacrysts and anorthosite xenolith-bearing dykes in the Narssarssuaq area, South Greenland. Rapp. Grønlands geol. Unders. 154, 49-59. 